\title{
Remembering Jean Sévry
}

Jean-Pierre Durix

\section{(2) OpenEdition}

\section{Journals}

Electronic version

URL: https://journals.openedition.org/ces/5518

DOI: $10.4000 /$ ces. 5518

ISSN: 2534-6695

\section{Publisher}

SEPC (Société d'études des pays du Commonwealth)

\section{Printed version}

Date of publication: 1 April 2012

Number of pages: 111-113

ISSN: 2270-0633

\section{Electronic reference}

Jean-Pierre Durix, "Remembering Jean Sévry", Commonwealth Essays and Studies [Online], 34.2 | 2012

Online since 19 April 2021, connection on 23 July 2021. URL: http://journals.openedition.org/ces/5518 ; DOI: https://doi.org/10.4000/ces.5518

\section{(c) (1) (9)}

Commonwealth Essays and Studies is licensed under a Licence Creative Commons Attribution - Pas d'Utilisation Commerciale - Pas de Modification 4.0 International. 


\section{Remembering Jean Sévry}

Jean Sévry, who was for many years professor at Université Paul Valéry in Montpellier, died at the end of May 2012. As a scholar, Jean was not obsessed with being in the limelight and often refused to conform to the norms which an academic eager to advance his career is supposed to respect. Yet he has been central in the study of African and in particular Southern African literature in France. Together with the regretted René Richard, his friend and long-time associate, he founded the CERPANA (Centre d'étude et de recherche sur les pays d'Afrique noire anglophone) at the Université Paul Valéry in the late 1970s. Their aim was to combine research and teaching on what was then a new field of investigation. Both René and Jean were passionately involved in developing new approaches to education in the wake of the 1968 "revolution." They were among the first in France to direct doctoral theses on African subjects and often with African students who came to study in Montpellier. Dealing with doctoral candidates from different backgrounds led them to invent new relationships between supervisor and student. Both Jean and René were always very respectful of their students' specific cultures and they tried to adapt their teaching to this challenging environment. With them supervision also involved helping their candidates to solve practical and personal difficulties inherent in their being uprooted from their network of family solidarity.

The importance of the new discipline they were developing was not always recognized as it should have been by some members of the university establishment and Jean had to fight hard to make sure that his speciality was respected for its true value. Such an atmosphere may be difficult to imagine for scholars beginning now in postcolonial literature and finding that their subject has almost become mainstream in Anglophone studies. Such was not the case in the 1980s and 90s when new approaches had to be invented and colleagues had to be convinced of the legitimacy of what was then considered as a minor discipline. For young academics like myself, Jean's CERPANA in the 1980s was a breath of fresh air with the opportunities it offered to meet other international specialists in the field and to take part in $\mathrm{PhD}$ committees on subjects closer to our own preoccupations. Jean was able to combine scholarly rigour and informality in human relationships. I will always remember arriving at Montpellier train station all dressed up for a $\mathrm{PhD}$ defence and Jean coming to collect me with his Vespa before taking me for a ride as far as his house in Castelnau. Another memorable occasion for me was in 1984, when Jean organized for Wole Soyinka to be given an honorary doctorate from his university. With the help of René Richard and Pierre Vitoux, he had managed to put together a major conference during which Wole Soyinka was made "citoyen d'honneur" of the city of Montpellier. In his acceptance speech at the town hall, Wole jokingly referred to his new position as one which allowed him to drink freely in every "café" and bar in town. This was two years before he received the Nobel prize in literature.

When I remember Jean, two other major projects come to mind: the first was the writing of the Anthologie critique de la littérature africaine anglophone which Christian Bourgois published in his 10/18 collection in 1983. It was the first time a major French publisher had brought out an anthology of writing from English-speaking Africa. The elaboration of the project with Denise Coussy and the regretted Jacqueline Bardolph was the occasion for many working sessions at our various homes during which our choices 
and texts were assessed and passionately discussed before they eventually evolved into a final draft for the publisher. Besides the result which readers can appreciate when consulting the book, these were marvellous opportunities for exchanging ideas, sharing our various experiences and approaches and learning to work as a collective. On top of that, we followed Wole Soyinka's recommendations and enjoyed very good and friendly meals accompanied by the French version of the best possible palm wine.

The other occasion when I was able to work closely with Jean was when the SEPC decided to focus their annual workshop at the SAES conference in Brest in May 1986 on the works of J. M. Coetzee. At the time, South Africa was such a controversial subject that anyone attempting to study a white South African writer ran the risk of being considered pro-apartheid. One shivers at the racist implications of such an accusation. In the face of a formidable slander machinery we nearly cancelled the workshop at the last minute and only decided to go on with our plan when we had made sure we had the support of senior members of the SAES such as Louis Roux, Jean-Pierre Martin, Jean Raimond and Pierre Vitoux, who solemnly defended us from unfounded accusations and reasserted the rights of imaginative creation over excessively restrictive political agendas. The workshop was finally held and issue 9.1 of Commonwealth is a testimony to the quality of the exchanges during that conference. Twenty-six years on, such a taboo on the study of a white South African writer - who has since received the Nobel prize in literature - is difficult to imagine. Yet this is an example of what we had to face with Jean Sévry.

In his approach to literature, Jean was influenced by philosophy, psychoanalysis, sociology and anthropology. He did not draw a line - or at least did not set up a hierarchy - between literary studies and what specialists of English in France call "civilisation." Towards the end of his university career, Jean was once again a pioneer in breaking the straitjacket of recognized disciplines. He soon realized the importance of developing a comparative approach to African literatures (in English, French, Portuguese...) which also include those published in different African languages. Thanks to Jean, I was able to meet many specialists in "francophonie" and Jean became very active in the newly founded APELA (Association pour l'étude des littératures africaines). Though Jean mainly studied the works of autochthonous writers, he did not neglect colonial literature, which, with the development of postcolonial studies, almost amounted to a form of political incorrectness. Jean calmly assumed his right to examine works in their own context and not with our own contemporary criteria for appreciation. Many of his later studies concern different aspects of religion, a subject which gradually took on increasing importance for him.

Throughout his life, Jean was passionately involved in his own writing and, after he retired, the translation of African writers into French became a favourite occupation, often in collaboration with "Mado", his wife and most faithful companion (see their translations of Jamal Mahjoub, Le Train des sables, Là d'où je viens [2004], Nubian Indigo [2006] with Editions Actes Sud).

After the death of Michel Fabre, one of Jean's mentors, and that of Jacqueline Bardolph, a very dear friend for both of us, Jean's disappearance is a hard blow to our discipline. Because of academics like himself, young researchers can now find it easier to be postcolonial specialists in a university environment. His visionary enterprises and uncompromising intellectual honesty make him an example to be followed. His love for 
working as part of a team in which hierarchy does not exist may seem slightly out of place in the present world. Yet I for one appreciate the value of Jean's principles which may well prove to be more promising than some of the individualistic values that are sometimes presented as the new norm. His works remain. Most memorable for me are his Afrique du sud, ségrégation et littérature. Anthologie critique (L'Harmattan, 1989) and Litteratures d'Afrique du sud (Karthala, 2007). Jean, now that you have passed over to the other side, all that is left is your writing and example, which remain with us, suggesting avenues for new developments.

Jean-Pierre DuRIX

Université de Bourgogne, Dijon 